\title{
A UTILIZAÇÃO DE MODELOS TRIDIMENSIONAIS NO ENSINO DE BIOLOGIA
}

\section{THE USE OF THREE-DIMENSIONAL MODEL IN THE TEACHING OF BIOLOGY}

\author{
João Victor de Almeida Gomes ${ }^{1}$; Tatiana Lima Alves²; Bruna Moura Cardoso Sousa ${ }^{3}$; Anna Luiza \\ Macedo Silva ${ }^{4}$; Adriana Ferreira de Sousa ${ }^{5}$.
}

\section{INTRODUÇÃOO}

O ensino de Biologia, tem se organizado de modo a favorecer o estudo de métodos científicos, conceitos e teorias. Essa prática é frequentemente considerada desestimulante pelo aluno, trazendo a necessidade de novas deliberações metodológicas por parte do professor.

Em várias circunstâncias, o docente não dispõe de recursos necessários para esclarecer fenômenos microscópicos, despercebidos a olho nu, o que dificulta o processo de construção do conhecimento e resulta na diminuição do entusiasmo dos discentes, uma vez que não participam de uma aprendizagem ativa, que pode ocasionar em uma visão simples e limitada da própria Biologia.

\begin{abstract}
Poucos profissionais de biologia possuem a habilidade ou têm a seu dispor ferramentas para trabalhar o conteúdo programático de forma efetivamente dinâmica e que permita ao aluno se envolver, desenvolver seu raciocínio, o espírito crítico, enfim, ser mais participante do processo de aprendizagem. A partir daí, busca-se selecionar os conceitos mais significativos (BRAGHINI, 1998, p.183).
\end{abstract}

Neste contexto, estudantes do curso de Ciências Biológicas do Instituto Federal do Piauí (IFPI) - Campus Teresina Central, após uma proposta da disciplina de Instrumentação para o Ensino Fundamental, produziram um modelo didático tridimensional numa perspectiva inclusiva, na medida em que respeitava princípios de acessibilidade para alunos com deficiência visual. Essa abordagem defende a importância da utilização de materiais simples como recursos educativos, uma vez que esse método tem como propósito o estreitamento das relações entre os aspectos lúdicos e cognitivos, visando uma maior apreensão dos conteúdos de Biologia e oferecendo oportunidades equivalentes de aprendizagem a todo o corpo discente.

\section{RELATO DE EXPERIÊNCIA}

Evidenciando que alunos com de deficiência visual possuem mais obstáculos que

\footnotetext{
${ }^{1}$ Graduando em Ciências Biológicas, Instituto Federal do Piauí - IFPI. E-mail: jvpcom62@gmail.com

${ }^{2}$ Graduanda em Ciências Biológicas, Instituto Federal do Piauí - IFPI. E-mail: alves.lima.tatiana@gmail.com

${ }^{3}$ Graduanda em Ciências Biológicas, Instituto Federal do Piauí - IFPI. E-mail: cardos.bmcs@ gmail.com

${ }^{4}$ Graduanda em Ciências Biológicas, Instituto Federal do Piauí - IFPI. E-mail: macedoannaluy@gmail.com

${ }^{5}$ Mestre em Educação, Professora Esp. em Educação Especial, Orientadora da disciplina de Instrumentação para o Ensino

Fundamental, Instituto Federal do Piauí - IFPI, E-mail: adrianafs27@gmail.com
} 
aqueles que dispõem da visão plena, os graduandos do quinto período do curso de Licenciatura em Ciências Biológicas, do Instituto Federal do Piauí - Campus Teresina Central, decidiram produzir um modelo tridimensional de formas bacterianas, baseado em conteúdos de microbiologia, contendo suas devidas identificações em Braille.

Para que o aluno com deficiência possa utilizar significativamente o modelo didático, a proposta é que o material escolhido trouxesse maior durabilidade e resistência. Portanto, as peças foram confeccionadas com massa de biscuit, em tamanhos consideráveis, apresentando cores fortes e formas distintas.

O processo artesanal consistiu em modelar a massa em formatos esféricos, espirais e cones arredondados nas extremidades, seguido de secagem em temperatura ambiente e coloridos artificialmente, com tinta para tecido de cores variadas. Separadamente, uma placa de vidro foi utilizada para suporte e fixação de pequenas caixas plásticas contendo as formas bacterianas confeccionadas anteriormente, com identificação tátil (em Braille) e visual em suas tampas.

Subsequentemente, foi apresentado o modelo didático para orientador e colegas de turma. Foi elaborado um plano de aula contendo propostas de abordagem embasadas em conteúdos de microbiologia, abrangendo os Ensinos de $1^{\circ}, 2^{\circ}$ e $3^{\circ}$ séries do ensino médio, seguida da apresentação deste recurso em uma Gincana de Materiais Didáticos, avaliada por três jurados.

Concluirmos que o modelo didático adaptados contribui para o melhor ensino aos alunos com deficiência visual. Porém é válido ressaltar que a preocupação com as cores e legendas digitadas faz com que o modelo possa ser utilizado para qualquer aluno.

Imagem 1: Exibição de modelos didáticos na gincana de modelos didáticos. Fonte: Própria
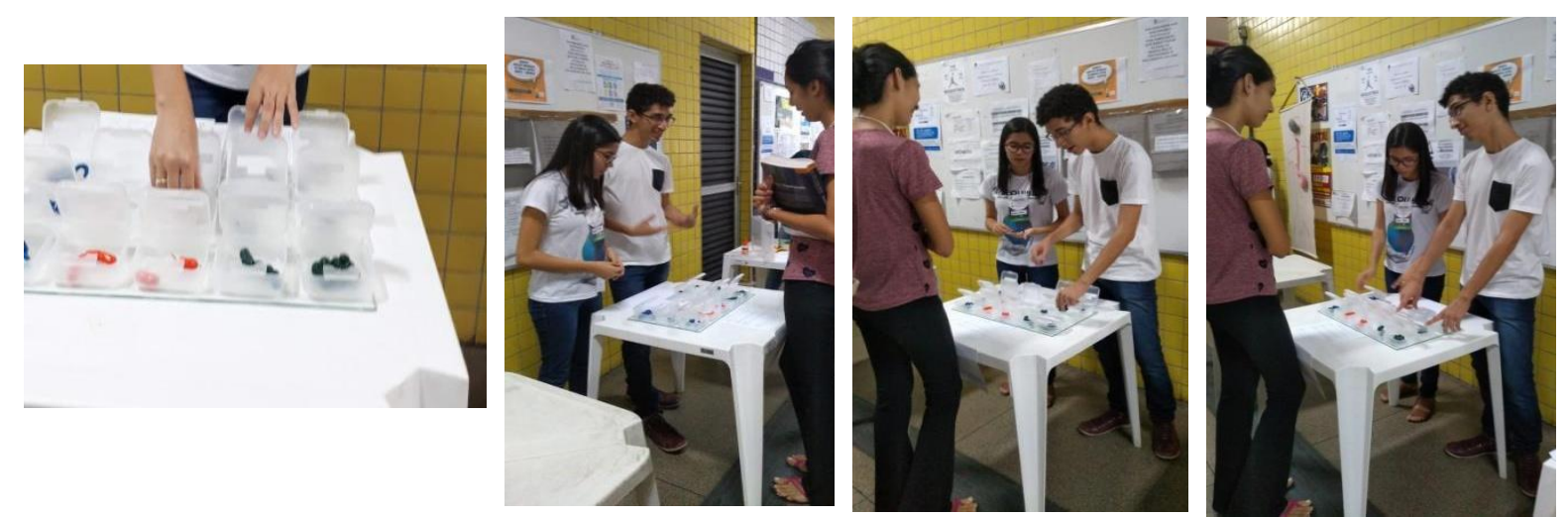

\section{CONSIDERAÇÕES}

A exposição do recurso didático sugerido possibilitou melhor compreensão dos temas 
apresentados para o estudo, trazendo questionamentos e discussões voltadas a acontecimentos cotidianos, como saneamento básico, higiene pessoal e prevenção de doenças.

Além disso, permitiu tanto para os alunos quanto para os licenciandos entender que nem sempre as metodologias adotadas nas ciências biológicas devem ser encaradas como memorização, fazendo-os repensar as estratégias adotadas na prática docente, pois, isoladamente, a verbalização de conteúdos não consegue, de forma relevante, dialogar com a realidade dos estudantes e "por isto mesmo, tendem a petrificar-se ou fazer algo quase morto" (FREIRE, 2004a, p. 57).

A vantagem da utilização de materiais lúdicos e concretos é que se permite o toque e a manipulação por alunos com deficiência visual, ampliando a aplicação em sala de aula, tendo em vista a inclusão socioeducativa, e diminuindo a distância entre o transmissor da informação (docente) e o receptor da informação (discente).

Concluirmos que "Não é transferir o conhecimento, mas criar as possibilidades para a sua produção e sua construção" (FREIRE, 2004b, p.47). Deste modo, entende-se que os estudantes são sujeitos ativos na elaboração do saber e que o educador deve ter como reflexão ensinar.

\section{REFERÊNCIAS}

BRAGHINI, C. R. Mudando o foco do professor para a atividade: novas tecnologias e metodologias no ensino de Biologia. In: VI Encontro Perspectivas Do Ensino De Biologia EPEB, 1997, São Paulo, São Paulo. Coletânea. São Paulo: FEUSP, 1998 p. 182-185.

FREIRE, P. Pedagogia do Oprimido. 38. ed. Rio de Janeiro: Paz e Terra, 2004.

FREIRE, P. Pedagogia da Autonomia: saberes necessários à prática educativa. 29. ed. Rio de Janeiro: Paz e Terra, 2004. 